\title{
TAP1 wt Allele
}

National Cancer Institute

\section{Source}

National Cancer Institute. TAP1 wt Allele. NCI Thesaurus. Code C52304.

Human TAP1 wild-type allele is located in the vicinity of $6 \mathrm{p} 21.3$ and is approximately $9 \mathrm{~kb}$ in length. This allele, which encodes antigen peptide transporter 1 protein, is involved in the presentation of antigen fragments to major histocompatibiltiy complex class I proteins. Mutations in the gene are associated with with ankylosing spondylitis, insulindependent diabetes mellitus, type I bare lymphocyte syndrome and celiac disease. 